DOI: https://doi.org/10.15688/jvolsu4.2016.4.1

UDC 902.26:903.7:94(398.1)«652»

Submitted: 15.03 .2016

LBC 63.3(0)32/(2)2:86.31

Accepted: 25.05 .2016

\title{
ON THE DISCOVERY OF EASTERN HELLENISTIC INITIATORY ALTAR OF THE 3RD - 1ST CENTURIES BC DEPICTING THE PLOT OF BULL SACRIFICE IN THE CITY OF STAVROPOL
}

\author{
Yuriy A. Prokopenko \\ North-Caucasus Federal University, Stavropol, Russian Federation
}

\begin{abstract}
The article is devoted to the semantic and chronological analysis of the images on the plate of white tuff discovered in the city of Stavropol. The central part of the relief is occupied with the image of table - an altar with hoisted bull head (in the background) and the hanging part of bull skin (in the foreground). Between the protruding edges of the hanging skin and lower to the ground (between the legs of the altar) an ancient Greek phrase carved in three lines. The composition is completed by flanking images of two figures in long robes depicted in profile, symmetrically turned to the head of the bull. The figure at the right is an image of a man with a long beard, the lower edge of which is bent forward (priest or king). The figure at the left is a female (queen). Both the man and the woman are holding ritual vessels in hands.

The plot of bull sacrifice is typical for the cultural traditions of ancient Greece as well as for ancient eastern states. The fact of combining images and inscriptions peculiar of the Hellenistic culture and ancient Iranian mythology on the Stavropol altar should be associated with the religious policy pursued by the Pontic kings since the second half of the 3rd century BC till the Common Era. This policy was focused on the gradual replacement of local cults by Greek ones in the official pantheon. The reasons for the Asia Minor altar existence in the Stavropol Upland include: 1) the military expeditions of the Sarmatians to Asia Minor in 2nd - 1st centuries BC; 2) the establishment of political and economic ties by the North Caucasus population with the state of Seleucids in the 2nd century BC, with Parthia in the 2nd -1 st centuries BC, and especially with the kingdom of Pontus in the 1st century BC.

Key words: Central North Caucasus, Stone altar, bull sacrifice, cult of Zeus, cult of Ahura Mazda, myths of Mithras, Pontus kingdom, Pontus Mithridates, Sarmatians.
\end{abstract}

УДК 902.26:903.7:94(398.1)《652»

Дата поступления статьи: 15.03.2016

ББК 63.3(0)32/(2)2:86.31

Дата принятия статьи: 25.05.2016

\section{О НАХОДКЕ ВОСТОЧНО-ЭЛЛИНИСТИЧЕСКОГО ПОСВЯТИТЕЛЬНОГО АЛТАРЯ ІІІ-І ВВ. ДО Н. Э. С ИЗОБРАЖЕНИЕМ СЮЖЕТА ЖЕРТВОПРИНОШЕНИЯ БЫКА В Г. СТАВРОПОЛЕ}

\author{
Юрий Анатольевич Прокопенко \\ Северо-Кавказский федеральный университет, г. Ставрополь, Российская Федерация
}

Аннотация. Статья посвящена семантическому и хронологическому анализу изображений на плите из белого туфа, выявленной на территории г. Ставрополя. Центральную часть рельефа занимает изображение стола-жертвенника с водруженной на него головой быка (на заднем плане) и свисающей частью бычьей 
шкуры (на переднем плане). Между выступающими краями свисающей шкуры и ниже (между ножками жертвенника) в три строки вырезана древнегреческая фраза. Сюжет, представленный на лицевой стороне предмета: жертвоприношение быка, характерен как для культурных традиций античной Греции, так и для древневосточных государств. Обстоятельство совмещения на ставропольском алтаре изображений и надписей, типичных для эллинистической культуры и древнеиранской мифологии, следует связывать с религиозной политикой понтийских царей, проводимой со второй половины III в. до н. э. и ориентированной на постепенное вытеснение местных культов из официального пантеона и замену их греческими. В качестве причин попадания на Ставропольскую возвышенность малоазийского алтарика следует назвать: 1) военные походы сарматов во II-І вв. до н. э. в Малую Азию; 2) налаживание политических и экономических связей населения Предкавказья с государством Селевкидов во II в. до н. э., с Парфией во II-I вв. до н. э. и особенно с Понтийским царством в I в. до н. э.

Ключевые слова: Центральное Предкавказье, каменный алтарь, жертвоприношение быка, культ Зевса, культ Ахура-Мазды, мифы о Митре, Понтийское царство, Понтийские Митридаты, сарматы.

В августе 1988 г. случайно в кладке опоры ограды приусадебного участка на ул. Герцена в г. Ставрополе был обнаружен интересный камень с рельефными изображениями. 22 ноября 1989 г. он поступил в собрание Ставропольского государственного историко-культурного и природно-ландшафтного музея-заповедника им. Г.Н. Прозрителева и Г.К. Праве ${ }^{1}$.

Предмет представляет собой плиту из белого армянского туфа трапециевидной пятиугольной формы. Размеры: В - 138 мм, Дл 144 мм, Ш - 38 мм $^{2}$. На камне просматриваются следы шлифовки. Левый угол плитки сколот. На лицевой и оборотной сторонах прослеживаются следы эрозии и затертостей, связанных с долгим употреблением.
На лицевой стороне в технике высокого рельефа вырезана композиция, видимо, изображающая эпизод ритуального действия жертвоприношения, связанного с культовой практикой (см. рис. 1-4).

Центральную часть рельефа занимает изображение стола-жертвенника с водруженной на него головой быка (на заднем плане) и свисающей частью бычьей шкуры (?) (на переднем плане). Между выступающими краями свисающей шкуры (?) и ниже (между ножками жертвенника) в три строки вырезана древнегреческая фраза. Верхний ярус составляют две затертые, слабо прослеживающиеся буквы, расположенные в углах между рельефно выступающими частями шкуры. Слева от ее затылочной части предположительно «N», справа «M».

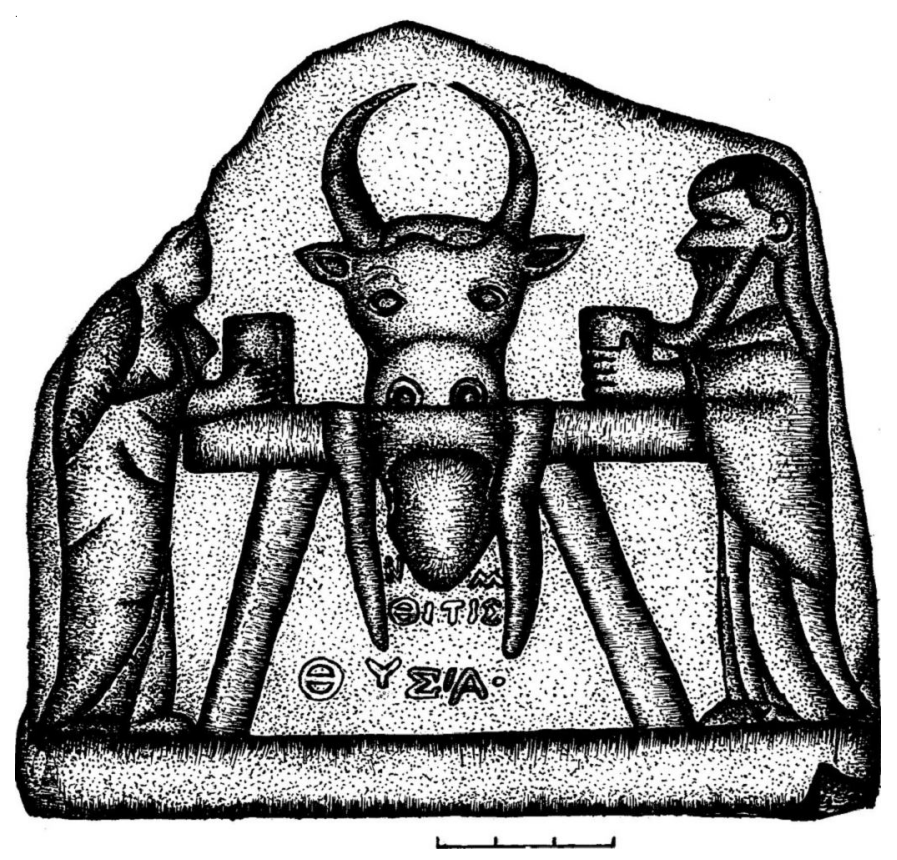

Рис. 1. Алтарь с изображением жертвоприношения быка (г. Ставрополь) - лицевая сторона 


\section{АРХЕОЛОГИЯ}

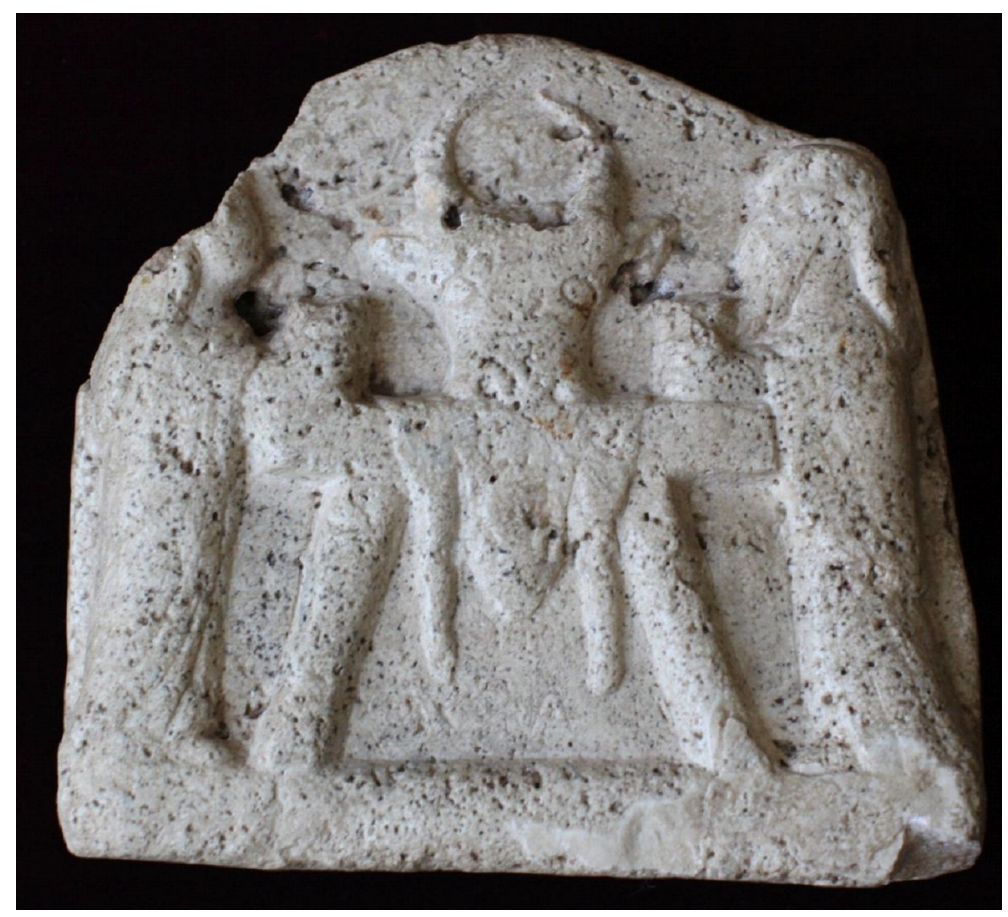

Рис. 2. Алтарь с изображением жертвоприношения быка (г. Ставрополь) - лицевая сторона

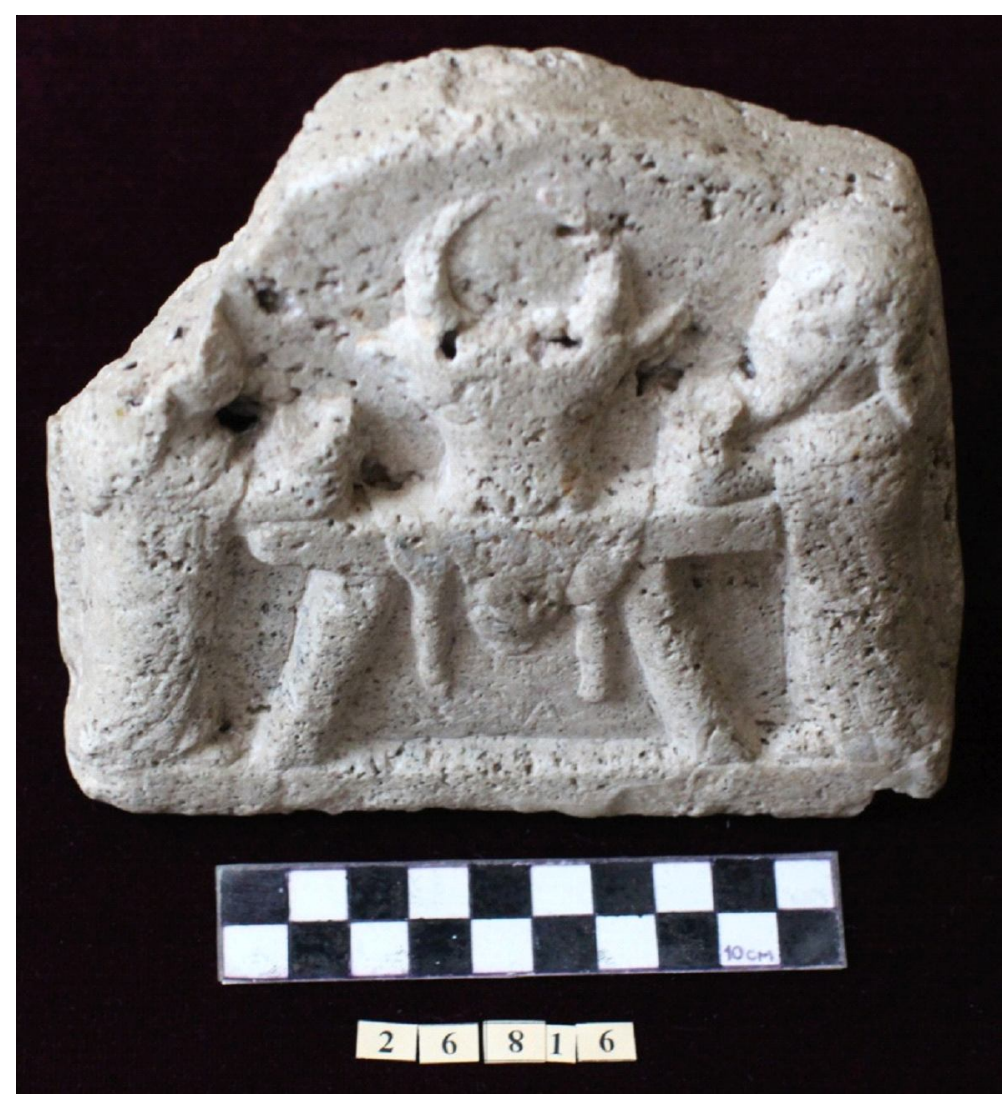

Рис. 3. Алтарь с изображением жертвоприношения быка (г. Ставрополь) - лицевая сторона (вид сверху) 


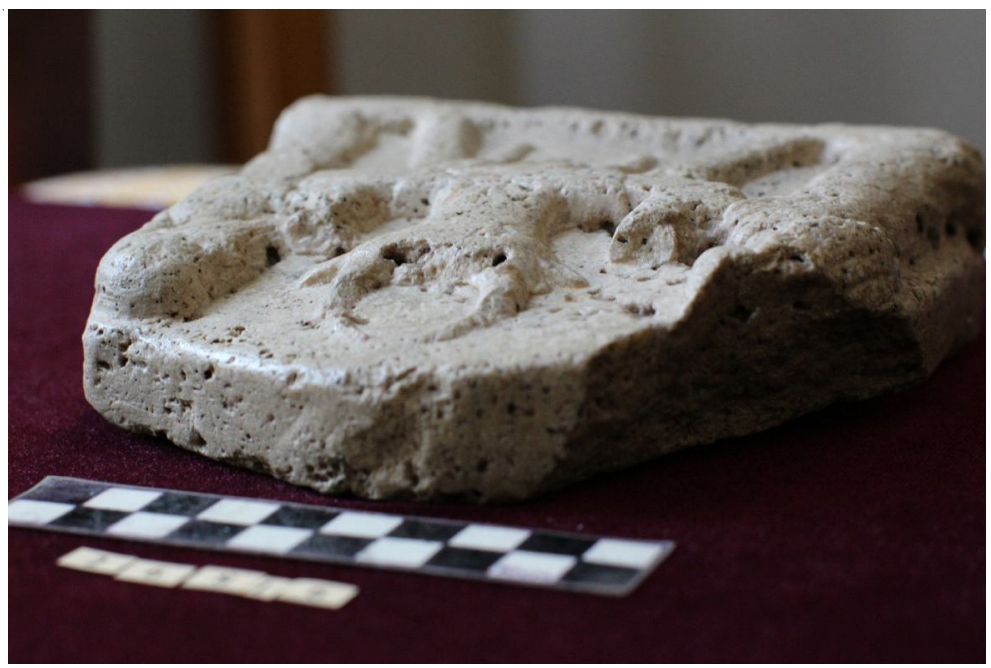

Рис. 4. Алтарь с изображением жертвоприношения быка (г. Ставрополь) - лицевая сторона (вид справа)

Вторая строка занимает пространство между выступающими фрагментами шкуры

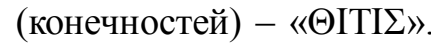

Характер сильной затертости двух верхних фрагментов фразы не позволяет их перевести. Возможно, данная часть надписи сохранилась частично.

Ниже краев шкуры между ножками жертвенника расположена третья часть надписи. Буквы более крупные, четко читающиеся -

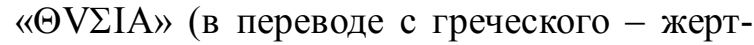
воприношение) ${ }^{3}$.

Композицию завершают фланкирующие изображение две фигуры, изображенные в профиль, в длинных одеяниях, симметрично повернутые к голове быка. Правая фигура является изображением мужчины с длинной бородой, нижний край которой загнут вперед (жрец или царь (?)). Левая фигура, судя по отсутствию бороды, женская (царица?). Мужчина и женщина держат в руках ритуальные сосуды. И алтарь, и царская чета (?) «стоят» на рельефно выступающем крае алтаря. Рельефные выступы рогов быка сохранились частично (наблюдаются следы сильной эрозии камня).

В нижней части мужской фигуры, на трапециевидно изображенной обуви (в профиль) прослеживается углообразный знак (буква?) v.

Оборотная сторона декорирована рисуночным письмом в пять ярусов. Они разделены параллельными врезными линиями. Изображения на правой части алтаря почти не пострадали от времени. Фигуры на левой половине сильно затерты, в некоторых случаях сохранились частично. Край первых трех горизонтальных полей - ярусов (сверху вниз) сколот.

На верхней строке помещены символы солнца и луны (справа налево - полумесяц и восьмилучевая звезда).

Второй ярус составляет композиция из антропоморфных и зооморфных фигур (справа налево): у края скола - загнутообразный отросток (нижняя конечность?); композиция из следующих друг за другом антропоморфной фигуры и животного с выгнутой в виде горба спиной (одногорбый верблюд?), изображенных в профиль. Вытянутые вперед руки человека опираются на отогнутый край предмета под острым углом, направленным в край ярусного поля (плуг?). Над спиной зооморфной фигуры вырезан крестообразный знак (солнце?); левее верблюда расположена антропоморфная фигура, развернутая в сторону животного. В левой руке человек (погонщик?) держит вытянутый предмет. Его правая рука отведена в сторону. Между левой рукой с палкой погонщика (?) и мордой верблюда (?) вырезан 3-образный знак. Левее изображена композиция из двух антропоморфных фигур, развернутых друг к другу. Правая показана на коленях с выгнутой дугой спиной, которая в позе подчинения смотрит на идущего к нему человека в округлом головном уборе (тиара?) с посохом в руке. Над спиной склоненного человека вырезан знак в виде овала с отростком. 
Третий ярус (справа налево): у края скола - загнутый в сторону края отросток (нижняя конечность?); зооморфная фигура на двух конечностях с дуговидно выгнутой грудной частью и хвостом, загнутым книзу (страус?). Композиция состоит из идущего влево человека (в профиль), вытянутыми руками держащего загнутый отросток, переходящий в область спины антропоморфной фигуры на коленях (в верхней части спины горбообразный выступ), опирающейся на руки. Человек, идущий влево и держащий в правой руке небольшой вытянутый предмет, с обеих сторон от его головы вырезаны углообразные знаки. Сидящая антропоморфная фигура (вправо) с приподнятой левой рукой и оттянутой назад правой; нижняя часть фигуры конусообразно расширяется (платье?); левая рука направлена в сторону прямоугольного предмета с вогнутыми сторонами, водруженного на черенкообразную подставку (женщина, вытягивающая из пряжи нити?). Человек, идущий влево, держащий в руках вытянутый предмет (свиток?), справа от его головы - два разнонаправленных углообразных знака. Сидящая на троне (в профиль) вправо антропоморфная фигура в высоком головном уборе (тиара?). Человек (правитель?) держит в руках посох.

Четвертый ярус (справа налево): в правом верхнем углу расположен развернутый под острым углом прямоугольник, имеющий в правом верхнем углу отросток (пустое поле после уборки урожая?). Композиция из двух человеческих фигур, показанных в профиль, развернутых друг к другу. Правая - в подчиненной позе на коленях, опирается на руки. Левая руками держит загнутый вытянутый предмет, опирающийся на прямоугольный предмет (конторка чиновника? виноградный пресс?). В верхней части - между лицом второй фигуры и прямоугольником (поля?) - помещены три знака (крестообразный между двух серповидных). Композиция из трех фигур - двух антропоморфных, развернутых друг к другу, и зооморфной с вытянутой шеей; человеческие фигуры касаются руками животного (с двух сторон). Антропоморфная фигуpa, идущая влево, в правой руке держит прямоугольный предмет, левая направлена вниз. Амфора, заключенная в серповидную подставку (?).
Пятый ярус (справа налево): антропоморфная фигура, идущая влево, правая рука приподнята (обрезана разрушенным краем), левая согнута в локте, направлена вперед. Композиция из двух антропоморфных фигур (в профиль), развернутых друг к другу. Правая фигура сидит в кресле и держит в руках птицу (охотничий сокол?). Левая фигура также показана в кресле, держит в руках серповидный предмет (ритон?). Антропоморфная фигура в позе подчинения - на коленях, опирается на прямоугольный предмет, справа от головы вырезан 3-образный знак. Антропоморфная фигура (лучник?): левая нога согнута и выставлена вперед, правая отставлена назад. Спина выгнута, левая рука приподнята и вытянута вперед, правая диаметрально противоположно оттянута назад, выше и правее левой руки вырезаны два углообразных знака. Антропоморфная фигура на коленях, развернутая вправо, руки вытянуты вперед. Плохо просматривающаяся зооморфная фигура, стоящая на задних лапах (?). Слабо выделяющаяся антропоморфная фигура в высоком головном уборе (тиара?).

Таким образом, ярусы занимают бытовые сцены из жизни правителей и обычных жителей, а также изображения животных. Некоторые фигуры стерты или просматриваются частично (см. рис. 5-6).

Аналогии данным изображениям мне неизвестны, но судя по характеру сюжетов следует предположить, что пять ярусов рисунков - это календарные изображения. Косвенно об этом свидетельствуют знаки солнца и луны, помещенные в верхнем ярусе. Как солнце и луна чередуются, так и времена года сменяют друг друга.

Возможно, судя по изображению пахаря, первый ярус означает весну, соответственно второй - лето; третий - осень (убранное поле, вино в амфоре); четвертый - зима (нет хозяйственных изображений, варианты отдыха - охота и винопитие).

Ритуал жертвоприношений, изображенный на лицевой стороне алтаря, характерен для всего эллинистического мира. Однако характер рельефных изображений отражает как элемент культурных традиций античной Греции, так и древневосточных государств. В первом случае это прежде всего древнегреческая надпись. 


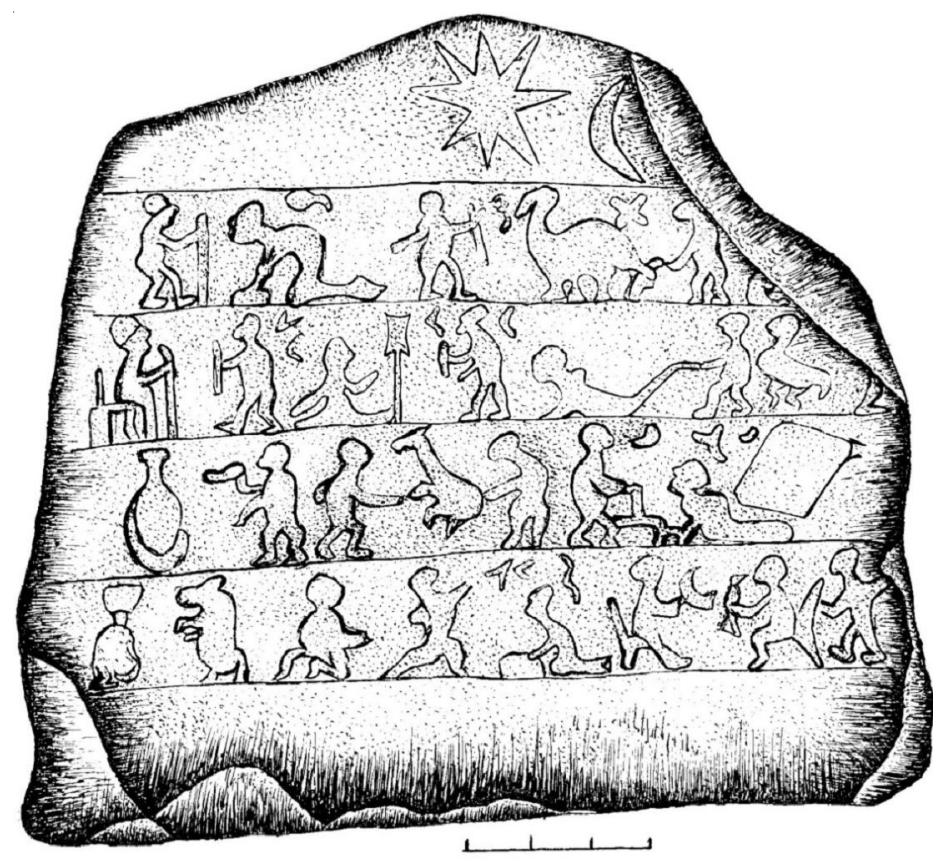

Рис. 5. Алтарь с изображением жертвоприношения быка (г. Ставрополь) - оборотная сторона

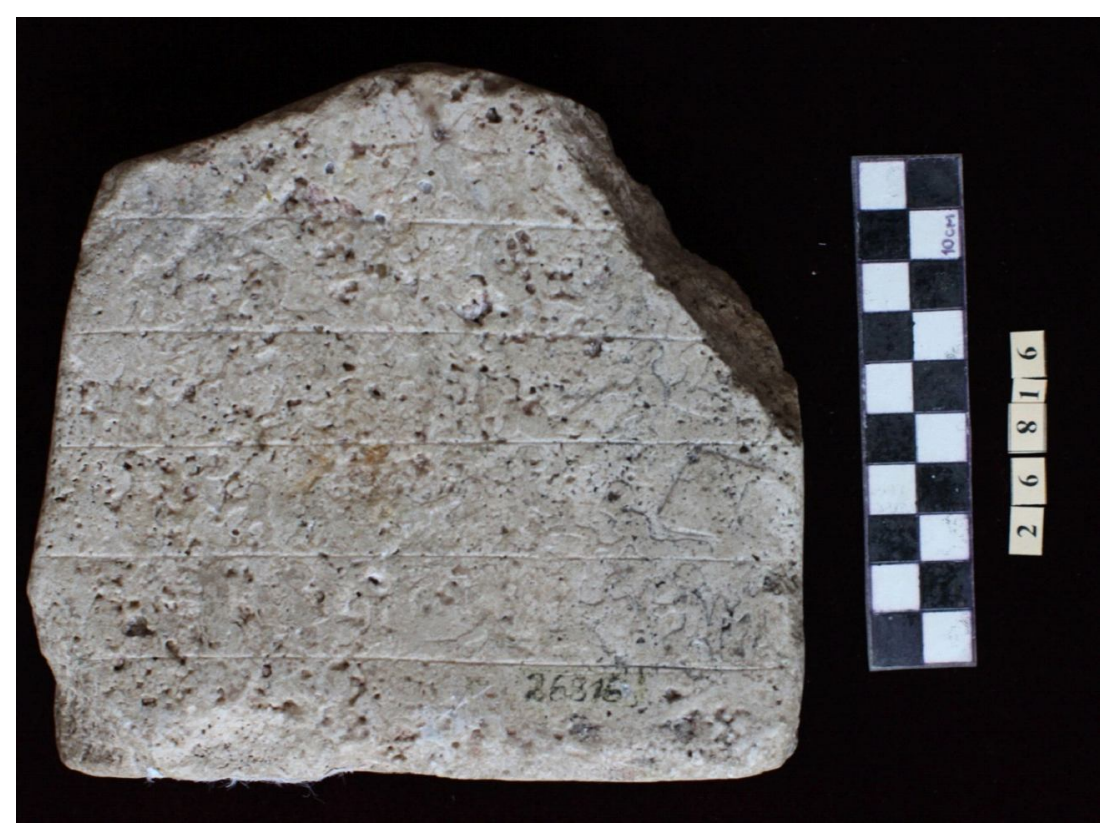

Рис. 6. Алтарь с изображением жертвоприношения быка (г. Ставрополь) - оборотная сторона

Во втором случае это детали иранского костюма, особенности окладистой бороды (у правой фигуры), а также изображения характерных для Востока солярных и лунарных символов, знаков священных животных и др.

Сюжет ставропольского алтаря связан с жертвоприношением быка, характерным как для эллинистических, так и древнеиранских культов. В Северном Причерноморье, в частности с IV в. до н. э. в Ольвии, производство свинцовых букраниев (изображения головы быка) и двулезвийных секир (лабрисов) было связано с культом Диониса [10, с. 203].

В Малой Азии жертвоприношение быка сопутствовало культу Зевса. Жители Гераклеи Понтийской считали Зевса Поарина покровителем лугов и пастбищ. Здесь данная ипостась Зевса наложилась на местного северо-анатолийского бога скотоводства и плодородия. 
Целый ряд изображений быка (в том числе головы) характерен для монет Амасии. В отдельных случаях на них отчеканен двухярусный костер с возложенным на него жертвенным животным - быком копытами вверх. Это относится к атрибутике Зевса Стратия (в римскую эпоху Зевса Никифора - символа императорской власти). Следует отметить, что атрибутика огня на этих монетах перекликается с иранским культом Ахура-Мазды, покровителя Ахеменидов, предков понтийских Митридатов и каппадокийских Ариаратидов. Существует аргументированное мнение о правомерности отождествления Зевса Стратия и персидского официального царского культа Ахура-Мазды, покровителя Ахеменидов, которым продолжали следовать понтийские Митридаты [4, с. 34-68].

Как уже было отмечено, на ставропольском изображении две (мужская и женская (?) фигуры (царская чета?)) держат сосуды, видимо, наполненные каким-то напитком. Возможно, он является атрибутом мифов о Митре. В частности, с быком связан главный эпизод таких мифов - об умыкании небесного быка и принесении его в жертву (по приказу Солнца). Жертвоприношение быка является сюжетом почти всех митраистских барельефов и росписей. Тело умирающего быка становится полем, на котором взошли все полезные травы и растения (Бундахишн, VI, E, 1-4). Спинной мозг стал основой для произрастания зерна, а кровь превращается в виноградную лозу, дающую священный напиток мистерий [12,p. 179, 186].

Затем дружба Митры и Солнца (Sol) скрепляется пиром, на котором они едят мясо быка. Характерно, что акт принесения в жертву быка проходил в пещере перед лицом солнца и луны (это перекликается с символами солнца и луны на оборотной стороне ставропольского алтаря). О космической структуре жертвоприношения свидетельствуют 12 знаков зодиака или 7 планет, а также символы ветров и четырех времен года $[11, \S 216,217]$ (возможно, на это указывают четыре линии изображений на оборотной стороне ставропольской находки) (см. рис. 5).

Также умерщвление первобыка Ахриманом перекликается с эсхатологическим жертвоприношением быка Хатайоша, в конце времен принесенного в жертву Саошьянтом и Ор- маздом. Согласно содержанию мифа изготовление из жира быка и его костного мозга напитка, смешанного с белой хаомой, сделает всех воскресших людей бессмертными [11, $\S 216,217 ; 13$, p. 350].

Обстоятельство совмещения на ставропольском алтаре изображений и надписей, характерных как для эллинистической культуры, так и древнеиранской мифологии, видимо, связано с религиозной политикой понтийских царей, проводимой со второй половины III в. до н. э. и ориентированной на постепенное вытеснение местных культов из официального пантеона и замену их греческими.

Большинство населения, включая эллинов и фрако-фригийцев Северной Анатолии, считало Митридатов чужими, пришлыми царями. Чтобы успешно пропагандировать их образ и создать царский культ, нужен был более известный местному населению бог, чем иранские Ахура-Мазда и Митра. Для этого более всего подходил Зевс. Следует согласиться с мнением С.Ю. Сапрыкина, отметившего, что ни Ахура-Мазда, ни Митра с течением времени не стали покровителями царской власти, хотя понтийские цари носили теофорное имя, связанное с Митрой [9, с. 34-68].

Свободное расположение фигур, качественная моделировка и передача отдельных деталей дают возможность отнести ставропольский алтарик к группе греко-персидских резных камней. Очень незначительное количество известных памятников эпиграфики и изображений жертвоприношения быка в Закавказье и их отсутствие в Центральном Предкавказье рассматриваемого периода говорят об уникальности находки.

Из известных нам наиболее близкой по композиции к ставропольской находке является мраморная плита, обнаруженная на территории Армении (см. рис. 7) [3, с. 38-39]. На этом камне, также как и на ставропольской плите, рельефно выступают голова и на переднем плане свисающая шкура закланного быка, которые положены на высокий жертвенник (справа и слева от головы быка на нем поставлены факелы).

Справа от жертвенника стоит царь в восточной (фригийской?) шапке на голове, держа в руке пучок колосьев, а рядом стоят три его сына с приподнятыми правыми руками. 


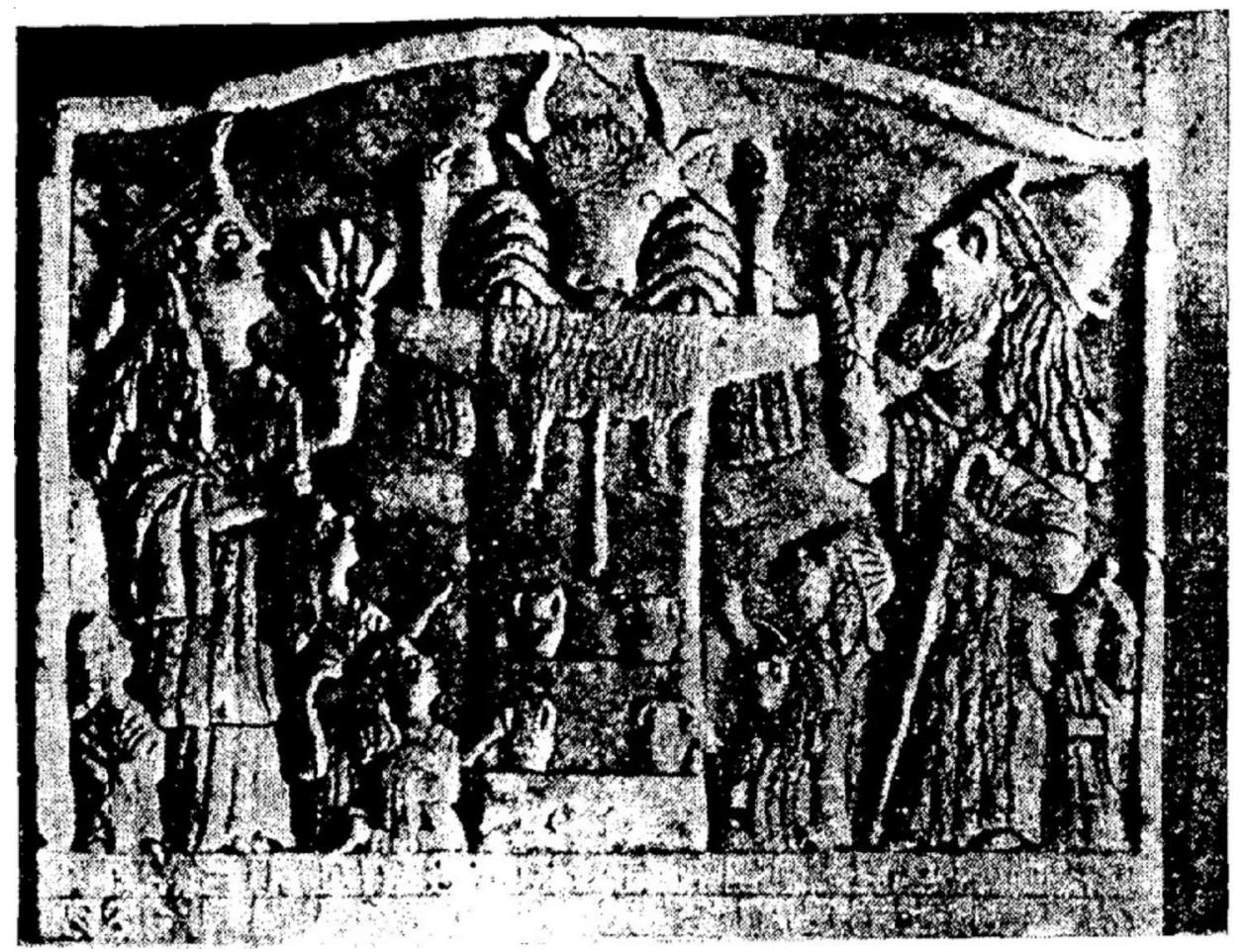

Рис. 7. Алтарь с изображением жертвоприношения быка V в. н. э. (по Г. Капанцян, Армения)

То же наблюдается с левой стороны, где с венцом на голове изображена царица, подносящая жертвенному быку такой же пучок из пяти колосьев, а группа дочерей (их также три) показана с приподнятыми левыми руками. Они, видимо, только что поставили на ступеньки алтаря сосуды с напитком (?). На ступеньках выставлены четыре таких сосуда, по два с каждой стороны. Царь держит в левой руке посох с загнутым кверху концом.

Под данным изображением вырезана надпись армянскими и грузинскими буквами «хуцури». Это свидетельствует о более позднем, в сравнении со ставропольской находкой, происхождении закавказской плиты. Г. Капанцян датировал ее V в. н. э. [3, с. 38]. Скорее всего, образцом для подобных изображений являлись эклектичные композиции алтариков последних веков до н. э.

В качестве причин попадания на Ставропольскую возвышенность малоазийского алтарика следует назвать: 1) военные походы сарматов во II-I вв. до н. э. в Малую Азию; 2) налаживание политических и экономических связей населения Предкавказья с государством Селевкидов во II в. до н. э., с Парфией во II-І вв. до н. э. и особенно с Понтийским царством в I в. до н. э.
К началу I в. до н. э. все побережье Черного моря (включая Боспорское царство) было объединено под властью Митридата IV Евпатора. В связи с тем, что Эвксинский Понт становится внутренним морем Понтийского царства, в данный период оживляется торговля.

Археологические материалы (находки в памятниках Предкавказья малоазийских стеклянных сосудов, пергамских керамических канфаров, фибул малоазийских типов, шлемов и др.) и нумизматические данные позволяют предположить, что с помощью союзных кочевников Митридат мог воздействовать через Центральное Предкавказье на активизацию военных действий Албании против римлян (находка в Чегемском могильнике понтийской медной монеты I в. до н. э., находки двух анонимных боспорских оболов I в. до н. э. в г. Ставрополе и его окрестностях; находки в могильнике Заманкул предметов черноморского и албанского производства) [4, с. 333335; 7, с. 117-118; 8, c. 69, 114].

В I в. до Н. э. через Ставропольскую возвышенность проходил северокавказский торговый путь, связывавший государства Закавказья и экономические центры Боспора. Об этом свидетельствует картография находок парфянских монет: драхмы: Орода II - 
ст. Батарейная (среднее течение р. Кубань), Вонона I (г. Новороссийск); Готарза - по одному экземпляру (г. Анапа), святилище Реком (Северная Осетия); Орода II (57-38 гг. до н. э.) найдена в г. Ставрополе; драхма Фраата IV (около 40 - 3 гг. до н. э.) обнаружена в окрестностях г. Дербента [1, с. $86 ; 2$, с. 29 , № 94, $102,110,116 a ; 4$, c. 114-115; 5, c. 63-65; 6, c. 17]. Локализация этих находок указывает на то, что они располагаются цепочкой по линии предполагаемой трассы данного пути.

Таким образом, кроме варианта попадания алтаря на территорию г. Ставрополя - завоза его в качестве военной добычи, другой возможной причиной является бытовая транспортная. Дипломат или торговец из Малой Азии, путешествующий с торговым караваном, мог потерять свой алтарик на одной из своих остановок на Ставропольской возвышенности (район г. Ставрополя), где выявлено значительное количество поселений и городищ со слоями последних веков до н. э.

\section{ПРИМЕЧАНИЯ}

1 Приношу искреннюю признательность коллективу отдела археологии Ставропольского государственного историко-культурного и природно-ландшафтного музея-заповедника им. Г.Н. Прозрителева и Г.К. Праве и лично директору музея Н.А. Охонько за оказанное содействие в процессе изучения алтаря и предоставленную возможность публикации.

2 В - высота; Дл - длина; Ш - ширина.

3 Работа с надписью осуществлялась сотрудником СГМЗ им. Г.Н. Прозрителева и Г.К. Праве В.А. Барановым в 1989 году.

\section{СПИСОК СОКРАЩЕНИЙ}

ВДИ - Вестник древней истории.

СГУ - Ставропольский государственный университет. верситет.

СКФУ - Северо-Кавказский федеральный уни-

ТОНГЭ - Труды отдела нумизматики Государственного Эрмитажа.

\section{СПИСОК ЛИТЕРАТУРЫ}

1. Голенко, К. В. Али-Байрамлинский клад и некоторые вопросы обращения парфянских монет в
Закавказье / К. В. Голенко, А. М. Раджабли // ВДИ. 1975. -№ 2. - С. 84-89.

2. Зограф, А. Н. Распространение находок античных монет на Кавказе / А. Н. Зограф // ТОНГЭ. 1945. - № 1. - C. $24-46$.

3. Капанцян, Г. А. О каменных стелах на горах Армении / Г. А. Капанцян. - Ереван : Изд-во АН Арм. АН CCP, 1952. $-52 \mathrm{c}$.

4. Прокопенко, Ю. А. Историко-культурное развитие населения Центрального Предкавказья во второй половине І тыс. до н. э. / Ю. А. Прокопенко. - Ставрополь : Изд-во СГУ, 2005. - 524 с.

5. Прокопенко, Ю. А. История северокавказских торговых путей IV в. до н. э. - ХІ в. н. э. - Ставрополь : Изд-во СГУ, 1999. - 319 с.

6. Прокопенко, Ю. А. Находки античных монет второй половины І тыс. до н. э. в Центральном и Восточном Предкавказье / Ю. А. Прокопенко // Нумизматический альманах. - 2001. - № 3 (18). C. 6-20.

7. Прокопенко, Ю. А. Сираки, тохары и племена Центрального Предкавказья в политических событиях II в. до н. э. - нач. І в. н. э. по письменным источникам, археологическим и нумизматическим данным / Ю. А. Прокопенко // Археология и этнология Северного Кавказа. - Нальчик : Изд. отд. КБИГИ, 2015. - Вып. 4. - С. 107-128.

8. Прокопенко, Ю. А. Скифы, сарматы и племена кобанской культуры в Центральном Предкавказье во второй половине I тыс. до н. э. Ч. ІІ / Ю. А. Прокопенко. - Ставрополь : Изд-во СКФУ, 2014. $-723 \mathrm{c}$.

9. Сапрыкин, С. Ю. Религия и культы Понта эллинистического и римского времени / С. Ю. Сапрыкин. - М. ; Тула : Триумф принт, 2009. - 385 с.

10. Шауб, И. Ю. Миф, культ, ритуал в Северном Причерноморье VII-IV вв. до н. э. / И. Ю. Шауб. - СПб. : Изд-во СПбГУ, 2007. - 482 с.

11. Элиаде, Э. История веры и религиозных идей. В 3 т. Т. 2. От Гаугамы Будды до триумфа христианства / Э. Элиаде. - М. : Критерион, 2002. $576 \mathrm{c}$.

12. Cumont, $F$. Textes et monuments figures relatifs aux mysteres de Mitra. In 2 vols. Vol. 1 / F. Cumont.Bruxelles : H. Lamertin, 1896. -263 p.

13. Duchesne-Guillemin, J. La religion de 1'Iran ancient / J. Duchesne-Guillemin. - Paris : Presses Universitaires de France, 1962. - 395 p.

\section{REFERENCES}

1. Golenko K.V., Radzhabli A.M. AliBayramlinskiy klad i nekotorye voprosy obrashcheniya parfyanskikh monet $\mathrm{v}$ Zakavkazye [Ali-Bairamlinsky Treasure and Some Issues of Parthian Coins Circulation 
Ю.А. Прокопенко. О находке восточно-эллинистического посвятительного алтаря III-I вв. до н. э.

in Transcaucasian Region]. Vestnik drevney istorii, 1975, no. 2, pp. 84-89.

2. Zograf A.N. Rasprostranenie nakhodok antichnykh monet na Kavkaze [Distribution of Finds of Ancient Coins in Caucasus]. Trudy otdela numizmatiki Gosudarstvennogo Ermitazha, 1945, no. 1 , pp. 24-46.

3. Kapantsyan G.A. O kamennykh stelakh na gorakh Armenii [About Stone Steles in the Mountains of Armenia]. Erevan, Izd-voANArmyanskoy SSR, 1952. $52 \mathrm{p}$.

4. Prokopenko Yu.A. Istoriko-kulturnoe razvitie naseleniya Tsentralnogo Predkavkazya vo vtoroy polovine I tys. do n.e. [Historical and Cultural Development of the Central Transcaucasian Region's Population in the Second Half of the 1st Millennium BC]. Stavropol, Izd-vo SGU, 2005. 524 p.

5. Prokopenko Yu.A. Istoriya severokavkazskikh torgovykh putey IVv. do n.e. $-X I$ v. n.e. [History of the North Caucasus Trade Routes of the 4th Century BC -11 th Century AD]. Stavropol, Izd-vo SGU, 1999.319p.

6. Prokopenko Yu.A. Nakhodki antichnykh monet vtoroy poloviny I tys. do n.e. $\mathrm{v}$ Tsentralnom $\mathrm{i}$ Vostochnom Predkavkazye [Found Ancient Coins of the Second Half of the 1st Millennium BC in the Central and East Transcaucasian Region]. Numizmaticheskiy almanakh, 2001, no. 3 (18), pp. 6-20.

7. Prokopenko Yu.A. Siraki, tokhary i plemena Tsentralnogo Predkavkazya v politicheskikh sobytiyakh II v. do n.e. - nachale I v. n.e. po pismennym istochnikam, arkheologicheskim i numizmaticheskim dannym [Shiraki, Tochars Tribes of Central Transcaucasian Region in the Political Events of the 2nd Century BC - Early 1st Century AD According to Written Sources, Archaeological and Numismatic Data]. Arkheologiya $i$ etnologiya Severnogo Kavkaza [Archaeology and Ethnology of the North Caucasus]. Nalchik, Izdatelskiy otdel KBIGI, 2015, iss. 4, pp. 107-128.

8. Prokopenko Yu.A. Skify, sarmaty i plemena kobanskoy kultury $v$ Tsentralnom Predkavkazye vo vtoroy polovine I tys. do n.e. Chast II [The Skythians, Sarmatians and Koban Culture Tribes in the Central Transcaucasian Region in the Second Half of the 1st Century BC. Part II]. Stavropol, Izd-vo SKFU, 2014. $723 \mathrm{p}$.

9. Saprykin S.Yu. Religiya i kulty Ponta ellinisticheskogo i rimskogo vremeni [Religion and Cults of Hellenistic Pont and Roman Times]. Moscow; Tula, Triumf print, 2009.385 p.

10. Shaub I.Yu. Mif, kult, ritual v Severnom Prichernomorye VII-IVvv. do n.e. [Myth, Cult, Ritual in the Northern Black Sea Region in the 7th-4th Centuries BC]. Saint Petersburg, Izd-vo SPbGU, 2007. $482 \mathrm{p}$.

11. Eliade E. Istoriya very i religioznykh idey. V 3 t. T. 2. Ot Gautamy Buddy do triumfa khristianstva [The History of Faith and Religious Ideas. In 3 vols. Vol. 2. From Gautama Buddha to the Triumph of Christianity]. Moscow, Kriterion Publ., 2002. 576 p.

12. Cumont F. Textes et Monuments figures relatifs aux Mysteres de Mitra. In 2 vols. Vol. 1. Bruxelles, H. Lamertin, 1896. 263 p.

13. Duchesne-Guillemin J. La religion de 1'Iran ancient. Paris, Presses Universitaires de France, 1962. $395 \mathrm{p}$.

\section{Information About the Author}

Yuriy A. Prokopenko, Doctor of Sciences (History), Associate Professor, Professor of Department of Cultural Studies and Arts, North-Caucasus Federal University, Pushkina St., 1, 355009 Stavropol, Russian Federation, z_proko_15@mail.ru.

\section{Информация об авторе}

Юрий Анатольевич Прокопенко, доктор исторических наук, доцент, профессор кафедры культурологии и искусств, Северо-Кавказский федеральный университет, ул. Пушкина, 1, 355009 г. Ставрополь, Российская Федерация, z_proko_15@mail.ru. 